\title{
Hydrogen isotopic composition of plant leaf wax in response to soil moisture in an arid ecosystem of the northeast Qinghai-Tibetan Plateau, China
}

\author{
Yuan YAO ${ }^{1,2}$, WeiGuo LIU ${ }^{1,2^{*}}$ \\ ${ }^{1}$ School of Human Settlements and Civil Engineering, Xi'an Jiaotong University, Xi'an 710049, China; \\ ${ }^{2}$ State Key Laboratory of Loess and Quaternary Geology, Institute of Earth Environment, Chinese Academy of Sciences, \\ Xi'an 710075, China
}

\begin{abstract}
The hydrogen isotopic composition of plant leaf wax $\left(\delta D_{\text {wax }}\right)$ is used as an important tool for paleohydrologic reconstruction. However, the understanding of the relative importance of environmental and biological factors in determining $\delta D_{\text {wax }}$ values still remains incomplete. To identify the effects of soil moisture and plant physiology on $\delta D_{\text {wax }}$ values in an arid ecosystem, and to explore the implication of these values for paleoclimatic reconstruction, we measured $\delta D$ values of soil water $\left(\delta D_{\text {water }}\right)$ and $\delta D_{\text {wax }}$ values in surface soils along two distance transects extending from the lakeshore to wetland to dryland around Lake Qinghai and Lake Gahai on the northeast Qinghai-Tibetan Plateau. The results showed that the $\delta D_{\text {water }}$ values were negatively correlated with soil water content (SWC) $\left(R^{2}=0.9166\right)$, and ranged from $-67 \%$ to $-46 \%$ with changes in SWC from $6.2 \%$ to $42.1 \%$ in the arid areas of the Gangcha (GCh) and Gahai $(\mathrm{GH})$ transects. This indicated that evaporative D-enrichment in soil water was sensitive to soil moisture in an arid ecosystem. Although the shift from grasses to shrubs with increasing aridity occurred in the arid area of the $\mathrm{GH}$ transect, the $\delta \mathrm{D}_{\text {wax }}$ values in surface soils from the arid areas of the two transects still showed a negative correlation with SWC $\left(R^{2}=0.6835\right)$, which may be due to the controls of primary evaporative D-enrichment in the soil water and additional transpirational $D$-enrichment in the leaf water on the $\delta D_{\text {wax }}$ values. Our preliminary research suggested that $\delta D_{\text {wax }}$ values can potentially be applied as a paleo-humidity indicator on the northeast Qinghai-Tibetan Plateau.
\end{abstract}

Keywords: hydrogen isotope; D-enrichment; soil water content; northeast Qinghai-Tibetan Plateau

Citation: Yuan YAO, WeiGuo LIU. 2014. Hydrogen isotopic composition of plant leaf wax in response to soil moisture in an arid ecosystem of the northeast Qinghai-Tibetan Plateau, China. Journal of Arid Land, 6(5): 592-600. doi: 10.1007/s40333-014-0005-9

The hydrogen isotopic composition of plant leaf wax $\left(\delta \mathrm{D}_{\text {wax }}\right)$ preserved in natural archives over geological timescales has been increasingly used as a promising paleohydrological proxy. Environmental water, as the ultimate hydrogen source of plant leaf wax, is considered as the primary controlling factor of $\delta D_{\text {wax }}$ values (Sachse et al., 2012). In large spatial scales, the fundamental control on $\delta \mathrm{D}_{\text {wax }}$ values is the hydrogen isotopic composition of precipitation (Hou et al., 2008; Liu and Yang, 2008; Tipple and Pagani, 2013). Given that the apparent hydrogen isotopic fractionation between source water and plant leaf wax $\left(\varepsilon_{\mathrm{wax} / \text { water }}\right)$ inte- grates transpirational D-enrichment in leaf water with biosynthetic fractionation, and some processes that control on $\delta \mathrm{D}_{\text {wax }}$ values are not well understood (Sachse et al., 2006, 2009; Smith and Freeman, 2006; Yang and Leng, 2009; Polissar and Freeman, 2010; McInerney et al., 2011), the effects of environmental and biological factors on $\delta \mathrm{D}_{\text {wax }}$ values are still being investigated in recent decades.

In general, $\delta \mathrm{D}_{\text {wax }}$ values of $\mathrm{C}_{4}$ grasses are slightly more positive than those of $\mathrm{C}_{3}$ grasses (Bi et al., 2005; Smith and Freeman, 2006). However, the $\delta \mathrm{D}_{\text {wax }}$ values are considerably affected by plant life forms (e.g. tree,

\footnotetext{
*Corresponding author: WeiGuo LIU (E-mail: liuwg@loess.llqg.ac.cn) Received 2013-07-23; revised 2013-11-17; accepted 2013-12-06

(C) Xinjiang Institute of Ecology and Geography, Chinese Academy of Sciences, Science Press and Springer-Verlag Berlin Heidelberg 2014
} 
shrub and grass) rather than by plant photosynthetic pathway $\left(\mathrm{C}_{3}\right.$ vs. $\left.\mathrm{C}_{4}\right)$ in northwestern China (Liu et al., 2006a) and in northeastern USA (Hou et al., 2007a). Interspecies variability in $\varepsilon_{\text {wax/water }}$ within growth forms also has significant variations that may be related to the differences in plant physiology, biochemistry and the timing of leaf wax synthesis (Chikaraishi and Naraoka, 2007; Hou et al., 2007a; Feakins and Sessions, 2010; Sachse et al., 2010, 2012). In addition, evapotranspiration (soil water evaporation and leaf water transpiration), which is controlled by environmental factors (e.g. temperature and humidity), drives D-enrichment in leaf water (Yapp and Esptein, 1982; Leaney et al., 1985; Yakir et al., 1990) and the signal can be recorded by $\delta \mathrm{D}_{\text {wax }}$ values (Kahmen et al., 2013a). Humidity, particularly in arid ecosystems, has an important role in determining $\delta \mathrm{D}_{\text {wax }}$ values through D-enrichment by evapotranspiration (Smith and Freeman, 2006). Liu and Huang (2005) showed that the changes in $\delta D_{\text {wax }}$ values in a paleosol profile are strongly consistent with those in aridity on the Chinese Loess Plateau.

The combined effects of environmental and biological factors on $\delta \mathrm{D}_{\text {wax }}$ values have recently been studied to determine their relative importance in the distribution of $\delta \mathrm{D}_{\text {wax }}$ signature. Enhanced D-enrichment with increasing aridity is partially countered by shifts in vegetation types across a large gradient of humidity and vegetation composition in southwestern USA (Hou et al., 2008). Plant physiology may exert a greater effect on $\delta D_{\text {wax }}$ values of grasses than environmental conditions (McInerney et al., 2011). Wang et al. (2013a) found that the $\delta D_{\text {wax }}$ values of $C_{31}$ and $C_{33}$ n-alkanes from a marine sediment core in the southwestern part of the Indian Ocean respond to the changes in $\mathrm{C}_{3} / \mathrm{C}_{4}$ vegetation. Whereas the simulated global patterns of D-enrichment in leaf water revealed that $\delta D_{\text {wax }}$ values could reflect evapotranspirational signal in arid or temperate regions (Kahmen et al., 2013b).

Therefore, determining the relative importance of environmental and biological factors controlling on $\delta D_{\text {wax }}$ values is important to examine the use of the values as a paleoclimatic proxy. In this study, we measured the $\delta \mathrm{D}$ values of soil water $\left(\delta \mathrm{D}_{\text {water }}\right)$ and $\delta \mathrm{D}_{\text {wax }}$ values in surface soils along two distance transects extending from the lakeshore to wetland to dryland around Lake Qinghai and Lake Gahai, to further understand the controlling factors and the implication of $\delta D_{\text {wax }}$ values for paleoclimatic reconstruction in the arid ecosystem.

\section{Study area and methods}

\subsection{Study area and samples}

We collected soil water and surface soil samples around Lake Qinghai and Lake Gahai in the northeast Qinghai-Tibetan Plateau (Fig. 1). Lake Qinghai $\left(36^{\circ} 32^{\prime}-37^{\circ} 15^{\prime} \mathrm{N}, 99^{\circ} 36^{\prime}-100^{\circ} 47^{\prime} \mathrm{E} ; 3,200 \mathrm{~m}\right.$ asl), the largest inland brackish lake in China, is characterized by an arid and semi-arid climate with a mean annual precipitation of $400 \mathrm{~mm}$ and a 10-year (1994-2004) mean summer temperature of $11.4^{\circ} \mathrm{C}$ (Henderson et al., 2003; Liu et al., 2008). Influenced by the East Asian summer monsoon, the Indian summer monsoon, the winter monsoon and the westerly jet stream, the region is highly sensitive to global climate change (An et al., 2000). Although summer has the highest precipitation, the potential evaporation $(800-1,200$ $\mathrm{mm}$ ) greatly exceeds precipitation in the lake (Liu et al., 2006b). Lake Gahai $\left(37^{\circ} 08^{\prime} \mathrm{N}, 97^{\circ} 33^{\prime} \mathrm{E}\right)$, a closed-basin lake in the northeast Qaidam Basin, is fed mostly by groundwater with no permanent inflow streams (Wang and Dou, 1998). Mean annual precipitation and mean summer temperature at nearby Delingha climate station $(2,928 \mathrm{~m}$ asl $)$, ca. $25 \mathrm{~km}$ north of Gahai, is about $160 \mathrm{~mm}$ and $15.6^{\circ} \mathrm{C}$, respectively. The mean annual potential evaporation is approximately $2,000 \mathrm{~mm}$ based on the average value for the period of 1971-2000 (Zhao et al., 2008).

Soil water and surface soil samples in the upper soil layer of $5 \mathrm{~cm}$ along two transects were collected in the summer of 2012 (Fig. 1 and Table 1). The Gangcha $(\mathrm{GCh})$ transect $\left(37^{\circ} 11^{\prime} 18^{\prime \prime}-37^{\circ} 12^{\prime} 15^{\prime \prime} \mathrm{N}, 100^{\circ} 06^{\prime} 41^{\prime \prime}\right.$ $\left.-100^{\circ} 06^{\prime} 51^{\prime \prime} \mathrm{E}\right)$ was in the north of Lake Qinghai within Gangcha county. Six soil water and surface soil samples from this transect were collected at a distance of ca. $0,150,225,1,100,1,700$ and $1,700 \mathrm{~m}$ from the lakeshore, respectively. The Gahai $(\mathrm{GH})$ transect $\left(37^{\circ} 09^{\prime} 33^{\prime \prime}-37^{\circ} 09^{\prime} 37^{\prime \prime} \mathrm{N}, 97^{\circ} 33^{\prime} 48^{\prime \prime}-97^{\circ} 34^{\prime} 14^{\prime \prime} \mathrm{E}\right)$ was in the northeast of Lake Gahai. Seven soil water and surface soil samples from this transect were collected at a distance of ca. 5, 55, 170, 300, 500, 600 and 700 $\mathrm{m}$ from the lakeshore, respectively. All samples were frozen and stored on dry ice in the field and then kept at $-20^{\circ} \mathrm{C}$ in the laboratory until analysis. 


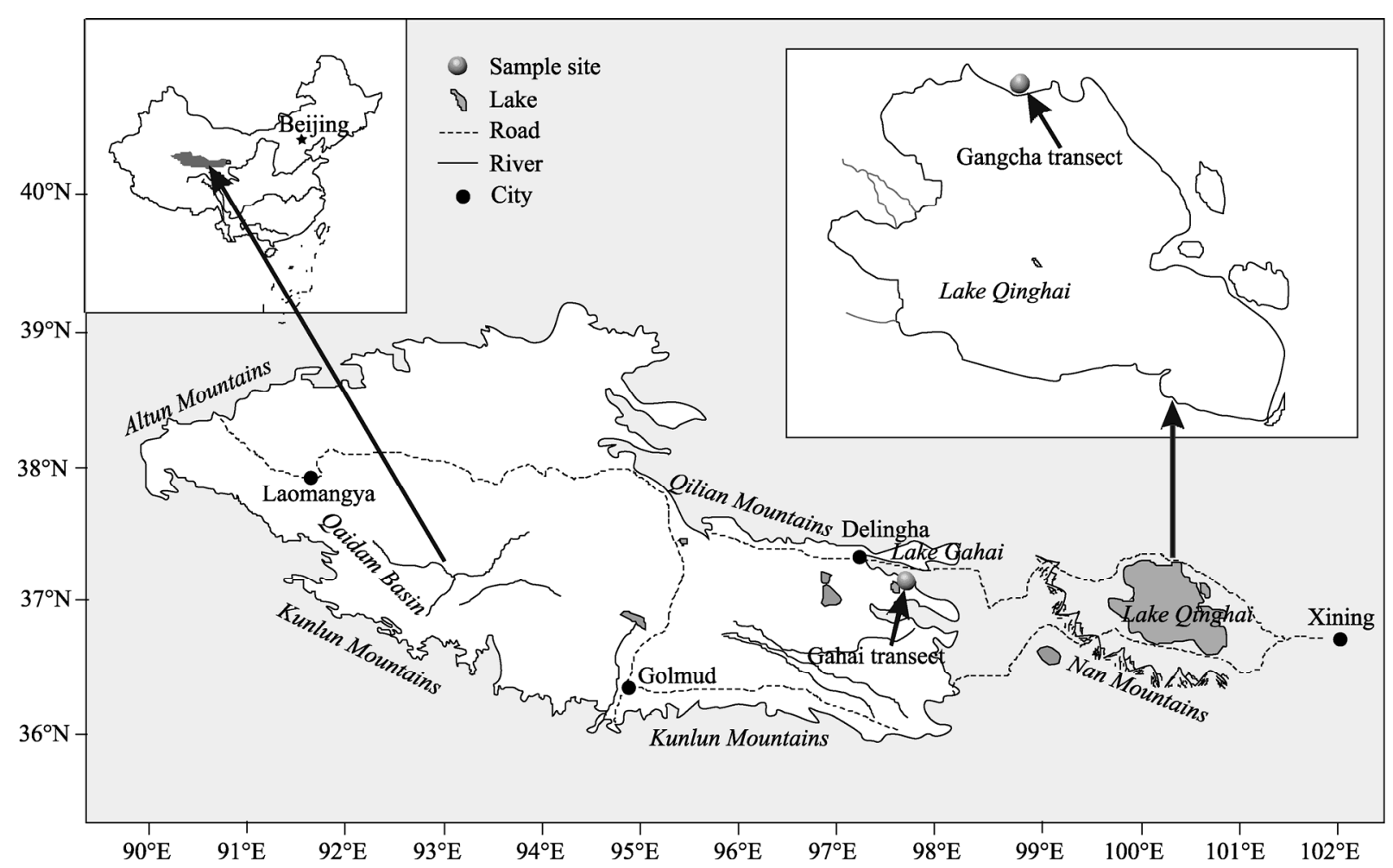

Fig. 1 Map of the Lake Qinghai and Lake Gahai on the northeast Qinghai-Tibetan Plateau, China

Table 1 SWC, $\delta D_{\text {water, }} \delta D_{\text {wax }}$ of $C_{31} n$-alkane and $\varepsilon_{\text {wax/water }}$ in the Gangcha (GCh) and Gahai $(G H)$ transects

\begin{tabular}{lcccccc}
\hline Sample number & $\begin{array}{c}\text { Distance from the } \\
\text { lakeshore }(\mathrm{m})\end{array}$ & Plant type & SWC $(\%)$ & $\delta \mathrm{D}_{\text {water }}(\%)$ & $\begin{array}{c}\delta \mathrm{D}_{\text {wax }} \text { of } \mathrm{C}_{31} \mathrm{n} \text {-alkane } \\
(\% 0)\end{array}$ & $\varepsilon_{\text {wax/water }}(\%)$ \\
\hline GCh12-2 & 0 & Grass & 58.0 & -45 & -194 & -156 \\
GCh12-3 & 150 & Grass & 51.9 & -49 & -192 & -150 \\
GCh12-4 & 225 & Grass & 48.8 & -40 & -181 & -147 \\
GCh12-5 & 1,100 & Grass & 42.1 & -67 & -204 & -147 \\
GCh12-6-1 & 1,700 & Grass & 26.1 & -59 & -192 & -142 \\
GCh12-6-2 & 1,700 & Grass & 39.1 & -64 & -200 & -145 \\
GH12-1 & 5 & Fern & 17.3 & -48 & -167 & -124 \\
GH12-2 & 55 & Fern grass & 15.9 & -50 & -193 & -150 \\
GH12-3 & 170 & Fern grass & 15.7 & -50 & -192 & -150 \\
GH12-4 & 300 & Grass & 17.9 & -50 & -199 & -157 \\
GH12-6 & 500 & Shrub & 16.4 & -52 & -170 & -125 \\
GH12-7 & 600 & Shrub & 15.9 & -46 & -163 & -123 \\
GH12-8 & 700 & Shrub & 6.2 & -47 & -158 & -117 \\
\hline
\end{tabular}

Note: SWC, Soil water content; $\delta \mathrm{D}_{\text {water }} \delta \mathrm{D}$ values of soil water; $\delta \mathrm{D}_{\mathrm{wax}}$, hydrogen isotopic composition of plant leaf wax; $\varepsilon_{\mathrm{wax} / \text { water }}$, apparent hydrogen isotopic fractionation between source water and plant leaf wax.

\subsection{Analytical methods}

1.2.1 Soil water content (SWC) analysis

SWC was obtained by measuring soil sample weight before and after freeze drying.

1.2.2 Extraction and purification of $n$-alkanes

Soil samples were freeze-dried and grounded using an agate mortar and pestle, and then sieved through a 100-mesh screen and homogenized. Methods for extraction, fractionation and purification of lipids were similar to those described by Zhang and Liu (2011). About $5 \mathrm{~g}$ sieved soil materials were extracted ultrasonically $(3 \times 20 \mathrm{~min})$ with dichloromethane (DCM) and methanol $(9: 1, \mathrm{v} / \mathrm{v})$. The solvent was then 
removed with a $\mathrm{N}_{2}$ stream. The n-alkane fractions were obtained by eluting the total extracts on a silica gel flash column (100-200 mesh silica gel) using hexane.

\subsubsection{Gas chromatography}

The n-alkanes were identified by comparing the retention times defined by Gas chromatography (GC) analysis of a mixed n-alkanes standard. GC was performed using an Agilent 6890 GC with a HP1-ms column $(60-\mathrm{m}$ height, $0.32-\mathrm{mm}$ inner diameter and $0.25-\mu \mathrm{m}$ film thickness) and a flame ionization detector. The samples were injected in split mode, with a GC inlet temperature of $310^{\circ} \mathrm{C}$ and a flow rate of 1.2 $\mathrm{mL} / \mathrm{min}$. The oven temperature program was $40^{\circ} \mathrm{C}(1$ min) to $150^{\circ} \mathrm{C}$ at $10^{\circ} \mathrm{C} / \mathrm{min}$ and then to $310^{\circ} \mathrm{C}(20 \mathrm{~min})$ at $6^{\circ} \mathrm{C} / \mathrm{min}$. GC analysis was carried out at the stable isotope laboratory of the Institute of Earth Environment, Chinese Academy of Sciences.

\subsubsection{Hydrogen isotope analysis}

Hydrogen isotope ratio of individual n-alkanes was analyzed using GC-thermal conversion-isotope ratio mass spectrometry (GC-TC-IRMS). A Thermo Trace Ultra GC was used along with a high temperature H/D pyrolysis reactor connected online to a Thermo Delta $\mathrm{V}$ Advantage isotope ratio mass spectrometer. Compounds separated with GC column (identical temperature program and GC column with an Agilent 6890 GC used for GC analysis) were converted to $\mathrm{H}_{2}$ by a pyrolysis reactor at $1,450^{\circ} \mathrm{C}$, and then $\mathrm{H}_{2}$ was introduced into the mass spectrometer. $\mathrm{H}_{3}$ factors were calculated daily using the same $\mathrm{H}_{2}$ reference gas. The precision of isotopic measurements of $\mathrm{H}_{2}$ reference gas after $\mathrm{H}_{3}$ factor correction was $1 \%$ or better. Analytical error was $<3 \%$ for samples. Compound specific hydrogen isotope analysis was carried out at the stable isotope laboratory of the Institute of Earth Environment, Chinese Academy of Sciences.

Hydrogen isotope ratio of soil water was analyzed using Isotope Water Analyzer (IWA) (LGR IWA-35EP) at the School of Environmental Science and Engineering, Chang'an University. The $\delta \mathrm{D}_{\text {water }}$ values were normalized to VSMOW using lab standards. The average precision of the $\delta \mathrm{D}_{\text {water }}$ measurements was $<0.3 \%$.

The apparent hydrogen isotopic fractionation between soil water and plant leaf wax $\left(\varepsilon_{\mathrm{wax} / \text { water }}\right)$ was calculated as Eq. 1:

$\varepsilon_{\mathrm{wax} / \mathrm{water}}=1000 \times\left[\left(\delta \mathrm{D}_{\mathrm{wax}}+1000\right) /\left(\delta \mathrm{D}_{\mathrm{water}}+1000\right)-1\right]$.

\section{Results and discussion}

\subsection{Effect of soil moisture on $\delta D_{\text {water }}$}

In an arid ecosystem where there is a significant D-enrichment in soil water towards the surface (Allison, 1982; Barnes and Allison, 1983; Tang and Feng, 2001), humidity plays an important role in determining $\delta D_{\text {water }}$ values by evaporation (Smith and Freeman, 2006; Hou et al., 2008; McInerney et al., 2011). In the present study, we selected two natural transects extending from the lakeshore to wetland to dryland around Lake Qinghai and Lake Gahai with a considerable difference in SWC $(6.2 \%$ to $42.1 \%)$. They provide ideal locations for investigating the effect of soil moisture on hydrogen isotopic compositions. Unfortunately, the $\delta \mathrm{D}_{\text {water }}$ values had a weak positive correlation $\left(R^{2}=0.4054\right)$ with $\mathrm{SWC}$ in the $\mathrm{GCh}$ transect, and a poor negative correlation $\left(R^{2}=0.1827\right)$ with SWC in the GH transect (Figs. 2a and $b$ ). This result is potentially due to the effect of

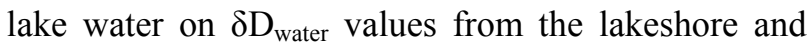
wetland in which soil water derives from a mixture of lake water and precipitation. In arid lake areas (e.g. Lake Gahai in the Qaidam Basin and Lake Qinghai) where evaporation exceeds precipitation (Liu et al., 2006b), lake water is more D-enriched than precipitation due to strong evaporation (Mügler et al., 2008; Xia et al., 2008; Aichner et al., 2010). Duan and Xu (2012) reported that $\delta D_{\text {water }}$ values from Lake Qinghai with a mean value of $4.7 \%$ were obviously more positive than those from the river water with a mean value of $-45.3 \%$. Potential evaporation $(800-1,200 \mathrm{~mm})$ greatly exceeds precipitation $(400 \mathrm{~mm})$ in the Lake Qinghai (Liu et al., 2006b), resulting in obvious D-enrichment of lake water relative to river water. We observed that $\delta D_{\text {water }}$ values (average value of $-45 \%$ ) from the lakeshore and wetland (within $225 \mathrm{~m}$ from the lakeshore) were more positive than those (average value of $-63 \%$ ) from the dryland $(225 \mathrm{~m}$ beyond the lakeshore) in the GCh transect (Table 1). Therefore, some lake water inputted into the lakeshore and the wetland, resulting in a poor correlation between the $\delta \mathrm{D}_{\text {water }}$ values and SWC.

To reduce the effect of lake water on $\delta \mathrm{D}_{\text {water }}$ values and further investigate the sensitivity of $\delta \mathrm{D}_{\text {water }}$ values to soil moisture, we analyzed the relationship between SWC and $\delta \mathrm{D}_{\text {water }}$ values in the arid areas of the GCh 

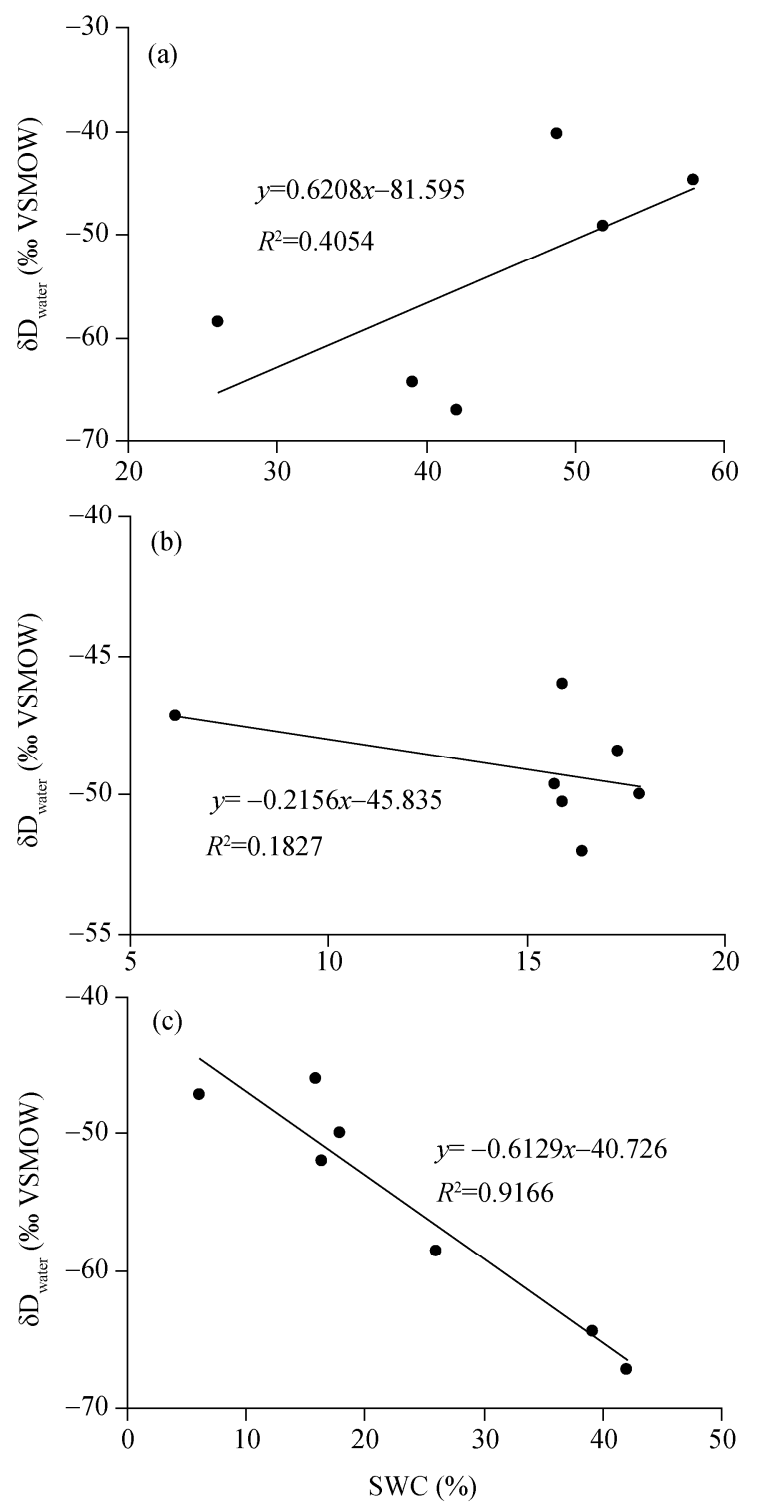

Fig. 2 Correlations between $\delta D_{\text {water }}$ values and soil water content (SWC) in the GCh transect (a), GH transect (b) and arid areas of the $\mathrm{GCh}$ and $\mathrm{GH}$ transects (c)

and GH transects ( $225 \mathrm{~m}$ beyond the lakeshore). The $\delta D_{\text {water }}$ values were significantly negatively correlated with SWC $\left(R^{2}=0.9166\right.$; Fig. $\left.2 \mathrm{c}\right)$, indicating that soil moisture exerts a major control on $\delta \mathrm{D}_{\text {water }}$ values in the arid areas. The negative correlation may be due to enhanced evaporative D-enrichment in soil water with decreasing SWC (Smith and Freeman, 2006; McInerney et al., 2011). The $\delta D_{\text {water }}$ values also showed a large variation from $-67 \%$ to $-46 \%$ with changes in SWC (6.2\%-42.1\%), suggesting that evaporative D-enrichment in soil water is sensitive to soil moisture in the arid areas. This observation is consistent with those from previous studies (Smith and Freeman, 2006;
Hou et al., 2008; McInerney et al., 2011), but contradicts the conclusion of Feakins and Sessions (2010). Feakins and Sessions (2010) measured the $\delta D_{\text {water }}$ values of tree xylem as a direct proxy of $\delta D_{\text {water }}$ values in southern California and found that little change existed in soil water D-enrichment. We speculated that deep-rooted sampled trees absorb more deep soil water that is more D-depleted relative to surface soil at a certain depth range due to decreased evaporation, and uptake of the D-depleted soil water may be the major cause of the little change in soil water D-enrichment.

\subsection{Effect of soil moisture on $\delta D_{\text {wax }}$ values in sur- face soils}

In our study, the GCh transect is dominated by single-species grasses at all sample sites, whereas there are obvious shifts in vegetation types, from ferns to grasses to shrubs, along the aridity gradient in the $\mathrm{GH}$ transect. These characteristics allowed us to assess the relative effect of plant physiology and soil moisture on hydrogen isotopic signatures of plant leaf wax in surface soils. In this study, we focused on the $\delta \mathrm{D}_{\text {wax }}$ values of $\mathrm{C}_{31} \mathrm{n}$-alkane as the representative isotope values of higher terrestrial plants, because $C_{31}$ n-alkane had the highest concentration of the long-chain n-alkanes in most of our samples. Considering the effect of lake water on $\delta D_{\text {water }}$ values from the lakeshore and wetland, we analyzed the $\delta \mathrm{D}_{\text {wax }}$ values of $\mathrm{C}_{31} \mathrm{n}$-alkane from surface soils in the arid areas of the GCh and $\mathrm{GH}$ transects.

The $\delta \mathrm{D}_{\text {wax }}$ values in surface soils were negatively correlated with SWC $\left(R^{2}=0.6835\right.$; Fig. 3$)$, indicating that soil moisture exerts a significant effect on $\delta \mathrm{D}_{\text {wax }}$

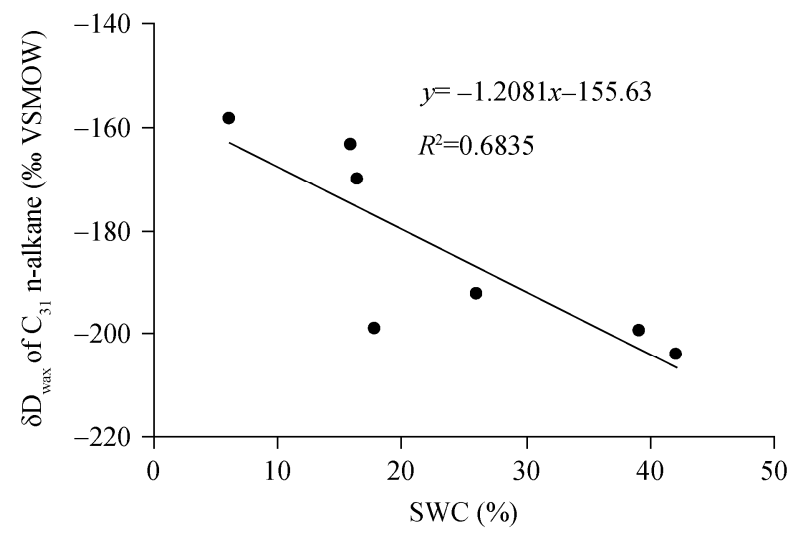

Fig. 3 Correlation between $\delta D_{\text {wax }}$ values of $C_{31} n$-alkane in surface soils and SWC in the arid areas of the GCh and GH transects 
values in surface soils despite the shifts in vegetation types in the GH transect. Nevertheless, soil moisture may have an indirect effect on $\delta \mathrm{D}_{\text {wax }}$ values in surface soils in this study. In the arid area of the GH transect, the shift from grasses to shrubs can result in more positive $\delta D_{\text {wax }}$ values in surface soils along the $G H$ transect, because shrubs have higher $\delta \mathrm{D}_{\text {wax }}$ values than grasses at the same site (Liu et al., 2006a; Hou et al., 2007a).

In order to understand how soil moisture affects the $\delta D_{\text {wax }}$ values in surface soils in our study, we examined and discussed soil water evaporation, leaf water transpiration and plant physiology as below.

First, the $\delta D_{\text {wax }}$ values in surface soils were positively correlated with the $\delta \mathrm{D}_{\text {water }}$ values $\left(R^{2}=0.6355\right.$; Fig. 4), indicating that soil water, as the ultimate source water of higher terrestrial plants, exerts the primary control on $\delta \mathrm{D}_{\text {wax }}$ values. This observation was supported by previous studies that $\delta \mathrm{D}$ values of precipitation as the first order of control are recorded by $\delta D_{\text {wax }}$ signals in large spatial scales (Hou et al., 2008; Liu and Yang, 2008; Tipple and Pagani, 2013). The $\delta \mathrm{D}_{\text {water }}$ values were also significantly negatively related to SWC in the arid areas of the $\mathrm{GCh}$ and $\mathrm{GH}$ transects due to enhanced evaporative D-enrichment in soil water with increasing aridity (Fig. 2c). Therefore, we suggested that the evaporative D-enrichment in soil water, which is controlled by soil moisture, plays an important role in determining $\delta \mathrm{D}_{\text {wax }}$ values, and this significant evaporation signal is recorded by $\delta D_{\text {wax }}$ values in surface soils.

Second, transpiration can drive D-enrichment in leaf water with increasing aridity (Yapp and Esptein, 1982; Leaney et al., 1985; Yakir et al., 1990), which has an additional critical effect on $\delta D_{\text {wax }}$ values (Smith and Freeman, 2006; Feakins and Sessions, 2010). The apparent hydrogen isotopic fractionation between soil water and plant leaf wax $\left(\varepsilon_{\mathrm{wax} / \mathrm{water}}\right)$ depends on both environmental and biological factors (Sessions, 2006; Liu and Yang, 2008; Sachse et al., 2009; Yang et al., 2011). Since there is no shift in vegetation types in the

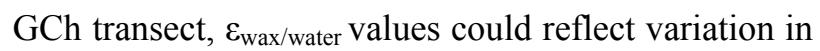
the leaf water transpiration. As shown in Fig. 5, $\varepsilon_{\text {wax/water }}$ values showed a significant negative correlation with $\operatorname{SWC}\left(R^{2}=0.8245\right)$, and a greater $\varepsilon_{\mathrm{wax} / \text { water }}$ values from plant (less hydrogen isotopic fractionation between plant leaf wax and source water) resulted from more transpirational D-enrichment in leaf water (Sachse et al., 2009). Theoretically, a site with lower SWC provides a drier growing environment for plants, and the changes in SWC reflect significant changes in moisture around plants growing on the soils in the two transects. Decreasing SWC therefore leads to increasing $\varepsilon_{\text {wax/water }}$ values through transpirational D-enrichment in leaf water, and the transpiration signal will be recorded by $\delta \mathrm{D}_{\text {wax }}$ values together with evaporation. $\mathrm{A}$ study of the model predictions revealed that evaporation and transpiration were highly sensitive to change in aridity, especially in an arid area, thus important information about aridity was recorded by $\delta D_{\text {wax }}$ values (Smith and Freeman, 2006). Both the climate chamber experiment and the observational study along climate gradient in northern Australia also provided strong evidences on the significant effect of evapotranspirational D-enrichment on $\delta \mathrm{D}_{\text {wax }}$ values (Kahmen et al., 2013a, b).

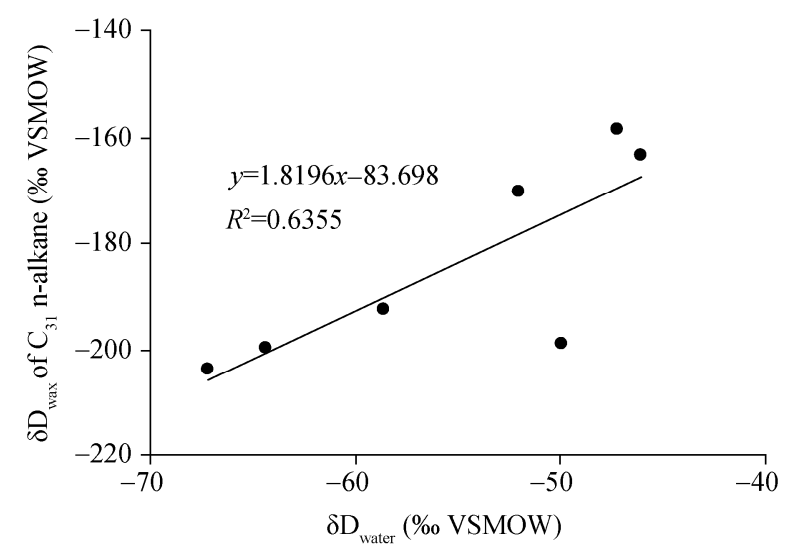

Fig. 4 Correlation between $\delta D_{\text {wax }}$ values of $C_{31} n$-alkane in

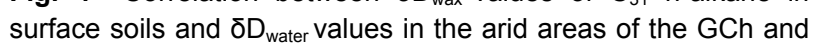
$\mathrm{GH}$ transects

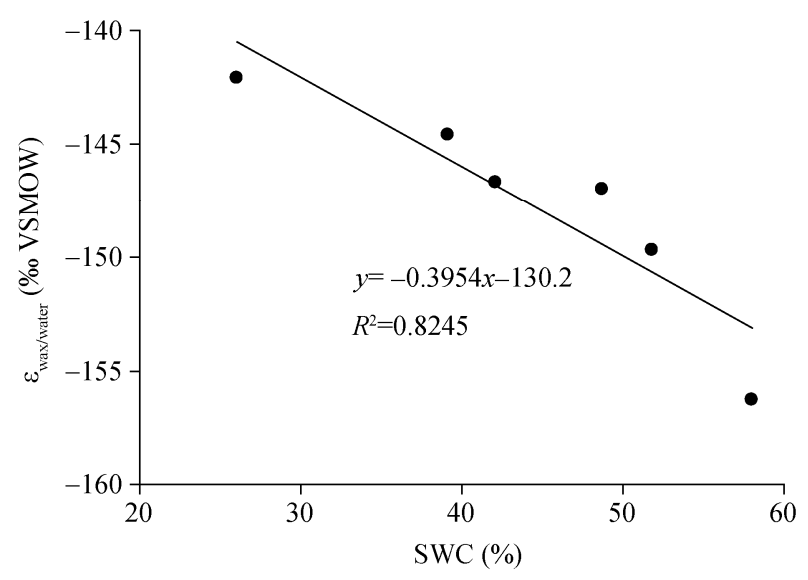

Fig. 5 Correlation between $\varepsilon_{\text {wax/water }}$ values and SWC in the GCh transect 
The slope of the relationship between $\varepsilon_{\mathrm{wax} / \text { water }}$ values and SWC in the GCh transect (-0.3954; Fig. 5) was larger than that between $\delta \mathrm{D}_{\text {water }}$ values and $\mathrm{SWC}$ in the arid areas of the GCh and $\mathrm{GH}$ transects (-0.6129; Fig. 2c), suggesting that soil water evaporation is more sensitive to soil moisture than leaf water transpiration for grasses. This result further demonstrated that evaporation is more important than transpiration in determining the $\delta \mathrm{D}_{\text {wax }}$ values, which is consistent with the finding from McIneyney et al. (2011), who found that soil evaporation correlating with humidity affected $\delta D_{\text {wax }}$ values rather than leaf transpiration for $\mathrm{C}_{3}$ and $\mathrm{C}_{4}$ shallow-rooted grasses. By contrast, deep-rooted shrubs and trees from an arid ecosystem in southern California did not show significant evaporative D-enrichment in soil water by comparing stem water and precipitation; instead, transpiration signal was recorded by $\delta \mathrm{D}_{\text {wax }}$ values (Feakins and Sessions, 2010). The contradicting results may be attributed to the distinct physiological characteristics of different plant life forms.

A significant difference in $\delta \mathrm{D}_{\text {wax }}$ values was also observed among different vegetation types (Liu et al., 2006a; Hou et al., 2007a), which may be attributed to the different physiological characteristics, such as leaf stomatal conductance (Pedentchouk et al., 2008), venation pattern (Helliker and Ehleringer, 2000) and hydraulic system (Hou et al., 2007b). Hou et al. (2008) found that the effect of humidity on evapotranspirational D-enrichment in leaf water was partially countered by the opposing influence of vegetation changes. McInerney et al. (2011) also suggested that plant physiology had a higher effect on $\delta D_{\text {wax }}$ values than evapotranspiration for grasses. In the GH transect, the $\varepsilon_{\text {wax/water }}$ values were weakly negatively correlated with SWC ( $R^{2}=0.2555$; Fig. 6), potentially because the enhanced transpirational D-enrichment in leaf water with increasing aridity was hindered by the influence of shifts in vegetation types. Therefore, a vegetation type may be a more important factor in determining $\delta \mathrm{D}_{\text {wax }}$ value compared with transpiration.

In summary, although there was the shift in vegetation types in the arid area of the $\mathrm{GH}$ transect with increasing aridity, the $\delta D_{\text {wax }}$ values in surface soils can still respond to soil moisture because the moisture exerted a primary control on $\delta \mathrm{D}_{\text {water }}$ values which determined the $\delta \mathrm{D}_{\text {wax }}$ values in surface soils in our study.

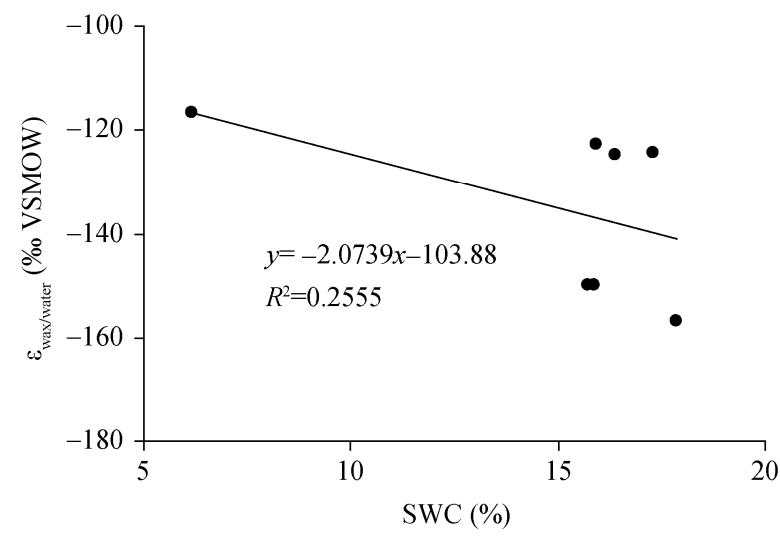

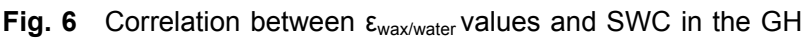
transect

\subsection{Implication for paleo-humidity variation}

Previous studies found that $\delta \mathrm{D}_{\text {wax }}$ values can reconstruct paleo-humidity in different sedimentary archives (Liu and Huang, 2005; Schefu $\beta$ et al., 2005; Wang et al., 2013b). A record of $\delta D_{\text {wax }}$ values from a loess profile spanning the last $130 \mathrm{ka}$ on the Chinese Loess Plateau showed that the changes in $\delta \mathrm{D}_{\text {wax }}$ values were strongly consistent with changes in aridity (Liu and Huang, 2005). In a $20-\mathrm{ka}$ record of $\delta \mathrm{D}_{\text {wax }}$ values from a marine sediment core close to the Congo River, the $\delta D_{\text {wax }}$ values were explained to be indicating wetter (more negative $\delta D_{\text {wax }}$ values) or drier (more positive $\delta D_{\text {wax }}$ values) conditions (Schefu $\beta$ et al., 2005).

Lake Qinghai or Lake Gahai sediments, ideal vehicle for paleoenvironmental research, generally integrated both environmental and ecological information over geological timescales. During the periods of drought, the drier climate resulted in higher $\delta \mathrm{D}_{\text {wax }}$ values partly due to enhanced evapotranspirational D-enrichment in leaf water (Liu and Huang, 2005). In addition, the shifts in vegetation types were controlled by the changes in humidity on the northeast Qinghai-Tibetan Plateau (Herzschuh et al., 2009). Chenopodiceae shrubs were more abundant during drier periods than wetter periods on the northeast Qinghai-Tibetan Plateau (Zhao et al., 2008) and had higher $\delta \mathrm{D}_{\mathrm{wax}}$ values than grasses (Liu et al., 2006a; Hou et al., 2007a). Thus a drier climate resulted in higher $\delta \mathrm{D}_{\text {wax }}$ values while a wetter climate resulted in lower $\delta D_{\text {wax }}$ values due to the combined effects of shifts in vegetation types (grasses and shrubs) controlled by humidity and evapotranspiration. Wang et al. (2013b) suggested that $\delta D_{\text {wax }}$ values from the 
sediment profile were mainly controlled by vegetation types (grasses and shrubs) which depended on moisture, and they also reconstructed regional changes in moisture in 1,700 years on the northeast Qinghai-Tibetan Plateau. In our study, evaporative D-enrichment in soil water controlled by moisture was identified as the primary control on the $\delta \mathrm{D}_{\text {wax }}$ values rather than the shifts in vegetation types (grasses and shrubs) in the arid areas of the GCh and GH transects. In conclusion, we suggested that $\delta \mathrm{D}_{\text {wax }}$ values can be used as a paleo-humidity indicator although the shifts in vegetation types (grasses and shrubs) ever existed on the northeast Qinghai-Tibetan Plateau.

\section{Conclusions}

From the investigation of $\delta \mathrm{D}_{\text {water }}$ and $\delta \mathrm{D}_{\text {wax }}$ values in surface soils along two distance transects extending from the lakeshore to wetland to dryland around Lake Qinghai and Lake Gahai, we found that $\delta \mathrm{D}_{\text {water }}$ values were negatively correlated with SWC, and were sensitive to soil moisture in the arid areas of the GCh and $\mathrm{GH}$ transects. The $\delta \mathrm{D}_{\text {wax }}$ values in surface soils were also negatively correlated with SWC in the arid areas of the GCh and GH transects, indicating that the $\delta \mathrm{D}_{\text {wax }}$ values can respond to the changes in soil moisture in our study.

A significant positive relationship between $\delta \mathrm{D}_{\text {water }}$ values and $\delta D_{\text {wax }}$ values in surface soils was observed, suggesting that evaporative D-enrichment in soil water was the primary control on the $\delta \mathrm{D}_{\text {wax }}$ values. The additional transpirational D-enrichment in leaf water likewise showed a strong negative correlation with SWC, and this signal can be recorded by $\delta \mathrm{D}_{\text {wax }}$ values together with evaporation as a result of changes in soil moisture. We suggested that the $\delta \mathrm{D}_{\text {wax }}$ values of lake sediments on the northeast Qinghai-Tibetan Plateau where shifts in vegetation types (grasses and shrubs) ever existed can be used as a paleo-humidity indicator.

\section{Acknowledgements}

This research was supported by the National Basic Research Program of China (2013CB955901) and the National Natural Science Foundation of China (41073018). We thank HuanYe WANG and YuXin HE for their help with sample collection. We are very grateful to Zheng WANG and YunNing CAO for their help with GC and GC-TC-IRMS analyses. We also appreciate two anonymous reviewers and the editors for their helpful comments.

\section{References}

Aichner B, Herzschuh U, Wilkes H, et al. 2010. $\delta$ D values of $n$-alkanes in Tibetan lake sediments and aquatic macrophytes: A surface sediment study and application to a $16 \mathrm{ka}$ record from Lake Koucha. Organic Geochemistry, 41: 779-790.

Allison G B. 1982. The relationship between ${ }^{18} \mathrm{O}$ and deuterium in water in sand columns undergoing evaporation. Journal of Hydrology, 55: 163-169.

An Z S, Porter S C, Kutzbach J E, et al. 2000. Asynchronous Holocene optimum of the East Asian monsoon. Quaternary Science Reviews, 19: 743-762.

Barnes C J, Allison G B. 1983. The distribution of deuterium and ${ }^{18} \mathrm{O}$ in dry soil: 1. Theory. Journal of Hydrology, 60: 141-156.

Bi X H, Sheng G Y, Liu X H, et al. 2005. Molecular and carbon and hydrogen isotopic composition of n-alkanes in plant leaf waxes. Organic Geochemistry, 36: 1405-1417.

Chikaraishi Y, Naraoka H. 2007. $\delta^{13} \mathrm{C}$ and $\delta \mathrm{D}$ relationships among three n-alkyl compound classes (n-alkanoic acid, n-alkane and n-alkanol) of terrestrial higher plants. Organic Geochemistry, 38: 198-215.

Duan Y, Xu L. 2012. Distributions of n-alkanes and their hydrogen isotopic composition in plants from Lake Qinghai (China) and the surrounding area. Applied Geochemistry, 27: 806-814.

Feakins S J, Sessions A L. 2010. Controls on the D/H ratios of plant leaf waxes in an arid ecosystem. Geochimica et Cosmochimica Acta, 74: 2128-2141.

Helliker B R, Ehleringer J R. 2000. Establishing a grassland signature in the veins: ${ }^{18} \mathrm{O}$ in the leaf water of $\mathrm{C}_{3}$ and $\mathrm{C}_{4}$ grasses. Proceedings of the National Academy of Sciences of the United States of America, 97: 7894-7898.

Henderson A C G, Holmes J A, Zhang J W, et al. 2003. A carbon and oxygen-isotope record of recent environment change from Lake Qinghai, NE Tibetan Plateau. Chinese Science Bulletin, 48: 1463-1468.

Herzschuh U, Kramer A, Mischke S, et al. 2009. Quantitative climate and vegetation trends since the late glacial on the northeastern Tibetan Plateau deduced from Koucha Lake pollen spectra. Quaternary Research, 71: 162-171.

Hou J Z, D'Andrea W J, MacDonald D, et al. 2007a. Hydrogen isotopic variability in leaf waxes among terrestrial and aquatic plants around Blood Pond, Massachusetts (USA). Organic Geochemistry, 38: 977-984.

Hou J Z, D'Andrea W J, MacDonald D, et al. 2007b. Evidence for water use efficiency as an important factor in determining the $\delta \mathrm{D}$ values of tree leaf waxes. Organic Geochemistry, 38: 1251-1255.

Hou J Z, D'Andrea W J, Huang Y S. 2008. Can sedimentary leaf waxes record $\mathrm{D} / \mathrm{H}$ ratios of continental precipitation? Field, model, and experimental assessments. Geochimica et Cosmochimica Acta, 72: 3503-3517.

Kahmen A, Schefu $\beta$ E, Sachse D. 2013a. Leaf water deuterium enrichment shapes leaf wax n-alkane $\delta \mathrm{D}$ values of angiosperm plants I: Experimental evidence and mechanistic insights. Geochimica et Cosmochimica Acta, 111: 39-49.

Kahmen A, Hoffmann B, Schefu $\beta$ E, et al. 2013b. Leaf water deuterium enrichment shapes leaf wax n-alkane $\delta \mathrm{D}$ values of angiosperm plants 
II: Observational evidence and global implications. Geochimica et Cosmochimica Acta, 111: 50-63.

Leaney F W, Osmond C B, Allison G B, et al. 1985. Hydrogen-isotope composition of leaf water in $\mathrm{C}_{3}$ and $\mathrm{C}_{4}$ plants: its relationship to the hydrogen-isotope composition of dry matter. Planta, 164: 215-220.

Liu W G, Huang Y S. 2005. Compound specific D/H ratios and molecular distributions of higher plant leaf waxes as novel paleoenvironmental indicators in the Chinese Loess Plateau. Organic Geochemistry, 36: 851-860.

Liu W G, Yang H, Li L W. 2006a. Hydrogen isotopic compositions of n-alkanes from terrestrial plants correlate with their ecological life forms. Oecologia, 150: 330-338.

Liu W G, Yang H. 2008. Multiple controls for the variability of hydrogen isotopic compositions in higher plant n-alkanes from modern ecosystems. Global Change Biology, 14: 2166-2177.

Liu W G, Liu Z H, Fu M Y, et al. 2008. Distribution of the $\mathrm{C}_{37}$ tetra-unsaturated alkenone in Lake Qinghai, China: a potential lake salinity indicator. Geochimica et Cosmochimica Acta, 72: 988-997.

Liu Z H, Henderson A C G, Huang Y S. 2006b. Alkenone-based reconstruction of late-Holocene surface temperature and salinity changes in Lake Qinghai, China. Geophysical Research Letters, 33, L09707. doi: 10.1029/2006GL026151.

McInerney F A, Helliker B R, Freeman K H. 2011. Hydrogen isotope ratios of leaf wax n-alkanes in grasses are insensitive to transpiration. Geochimica et Cosmochimica Acta, 75: 541-554.

Mügler I, Sachse D, Werner M, et al. 2008. Effect of lake evaporation on $\delta$ D values of lacustrine $\mathrm{n}$-alkanes: A comparison of Nam Co (Tibetan Plateau) and Holzmaar (Germany). Organic Geochemistry, 39: 711-729.

Pedentchouk N, Sumner W, Tipple B, et al. 2008. $\delta^{13} \mathrm{C}$ and $\delta \mathrm{D}$ compositons of $n$-alkanes from modern angiosperms and conifers: An experimental set up in central Washington State, USA. Organic Geochemistry, 39: 1066-1071.

Polissar P J, Freeman K H. 2010. Effects of aridity and vegetation on plant-wax $\delta \mathrm{D}$ in modern lake sediments. Geochimica et Cosmochimica Acta, 74: 5785-5797.

Sachse D, Radke J, Gleixner G. 2006. $\delta$ D values of individual n-alkanes from terrestrial plants along a climatic gradient: Implications for the sedimentary biomarker record. Organic Geochemistry, 37: 469-483.

Sachse D, Kahmen A, Gleixner G. 2009. Significant seasonal variation in the hydrogen isotopic composition of leaf-wax lipids for two deciduous tree ecosystems (Fagus sylvativa and Acer pseudoplatanus). Organic Geochemistry, 40: 732-742.

Sachse D, Gleixner G, Wilkes H, et al. 2010. Leaf wax n-alkane $\delta$ D values of field-grown barley reflect leaf water $\delta \mathrm{D}$ values at the time of leaf formation. Geochimica et Cosmochimica Acta, 74: 6741-6750.

Sachse D, Billault I, Bowen G J, et al. 2012. Molecular paleohydrology: interpreting the hydrogen-isotopic composition of lipid biomarkers from photosynthesizing organisms. Annual Review of Earth and
Planetary Sciences, 40: 221-249.

Schefu $\beta$ E, Schputen S, Schneider R R. 2005. Climatic controls on central African hydrology during the past 20,000 years. Nature, 437: 1003-1006.

Sessions A L. 2006. Seasonal changes in D/H fractionation accompanying lipid biosynthesis in Sparina alterniflora. Geochimica et Cosmochinica Acta, 70: 2153-2162.

Smith F A, Freeman K H. 2006. Influence of physiology and climate on $\delta \mathrm{D}$ of leaf wax n-alkanes from $\mathrm{C}_{3}$ and $\mathrm{C}_{4}$ grasses. Geochimica et Cosmochimica Acta, 70: 1172-1187.

Tang K L, Feng X H. 2001. The effect of soil hydrology on the oxygen and hydrogen isotopic compositions of plants' source water. Earth and Planetary Science Letters, 185: 355-367.

Tipple B J, Pagani M. 2013. Environmental control on eastern broadleaf forest species' leaf wax distributions and D/H ratios. Geochimica et Cosmochimica Acta, 111: 64-77.

Wang S M, Dou H S. 1998. Chinese Lake. Beijing: Science Press, 493-494.

Wang Y V, Larsen T, Leduc G, et al. 2013a. What does leaf wax $\delta \mathrm{D}$ from a mixed $\mathrm{C}_{3} / \mathrm{C}_{4}$ vegetation region tell us? Geochimica et Cosmochimica Acta, 111: 128-139.

Wang Z, Liu W G, Liu Z H, et al. 2013b. A 1700-year n-alkanes hydrogen isotope record of moisture changes in sediments from Lake Sugan in the Qaidam Basin, northeastern Tibetan Plateau. The Holocene, doi: 10.1177/0959683613486941.

Xia Z H, Xu B Q, Mügler I, et al. 2008. Hydrogen isotope ratios of terrigenous $n$-alkanes in lacustrine surface sediment of the Tibetan Plateau record the precipitation signal. Geochemical Journal, 42: 331-338.

Yakir D, Deniro M J, Gat J R. 1990. Natural deuterium and O-18 enrichment in leaf water of cotton plants grown under wet and dry condition: evidence for water compartmentation and its dynamics. Plant, Cell \& Environment, 13: 49-56.

Yang H, Leng Q. 2009. Molecular hydrogen isotope analysis of living and fossil plants: Metasequoia as an example. Progress in Natural Science, 19: 901-912.

Yang H, Liu W G, Leng Q, et al. 2011. Variation in n-alkanes $\delta D$ values from terrestrial plants at high latitude: Implications for paleoclimate reconstruction. Organic Geochemistry, 42: 283-288.

Yapp C J, Epstein S. 1982. A reexamination of cellulose carbon-bound hydrogen $\delta \mathrm{D}$ measurements and some factors affecting plant-water D/H relationships. Geochimica et Cosmochimica Acta, 46: 955-965.

Zhang P, Liu W G. 2011. Effect of plant life form on relationship between $\delta \mathrm{D}$ values of leaf wax n-alkanes and altitude along Mount Taibai, China. Organic Geochemistry, 42: 100-107.

Zhao Y, Yu Z C, Chen F H, et al. 2008. Sensitive response of desert vegetation to moisture change based on a near-annual resolution pollen record from Gahai Lake in the Qaidam Basin, northwest China. Global and Planetary Change, 62: 107-114. 